\title{
UPAYA MEMPERPANJANG MASA SIMPAN ANDALIMAN (Zanthoxylum acanthopodium D) STUDI KASUS DESA BANDAR HUTA USANG KABUPATEN DAIRI
}

\author{
Roida E. Sinaga ${ }^{1)}$ Healthy A. Prasetyo ${ }^{2)}$ \\ ${ }^{1) 2}$ Universitas Quality \\ Email: roidasinaga20@gmail.com
}

\begin{abstract}
Abstrak
Andaliman (Zanthoxylum acanthopodium DC.) merupakan tanaman yang memiliki karakteristik mudah busuk dan berjamur sehingga setelah panen perlu penanganan pascapanen. Metode yang tepat digunakan adalah teknik pengawetan. Penelitian ini bertujuan untuk mengetahui pengaruh aplikasi $\mathrm{CaCl} 2$ (Kalsium Klorida) terhadap lama penyimpanan andaliman (Zanthoxylum acanthopodium DC).

Pada penelitian sebelumnya diperoleh hasil bahwa perlakuan yang terbaik adalah dengan perendaman andaliman dengan Kalsium Klorida $(\mathrm{CaCl} 2)$ pada konsentrasi 0,45\% selama 40 menit. Pada penelitian ini akan diaplikasikan Kalsium Klorida 0,45\% untuk melihat pengaruh lama penyimpanan andaliman. Andaliman akan disimpan pada tingkatan lama penyimpanan 4 hari, 5hari, 6 hari dan 7 hari. Parameter yang diamati adalah kadar air, susut bobot, kadar minyak atsiri dan uji organoleptik warna, aroma dan tekstur. Penelitian

menggunakan metode rancangan acak lengkap faktorial, yaitu lama penyimpanan terdiri dari4 taraf yaitu $\mathrm{L} 1=4$ hari : $\mathrm{L} 2=5$ hari : $\mathrm{L} 3=6$ hari : $\mathrm{L} 4=7$ hari. Hasil penelitian ini memiliki target berupa publikasi satu artikel ilmiah dalam jurnal nasional ber ISSN. Penelitian ini mengacu pada teknologi pascapanen dan rekayasa teknologi pengolahan pangan berupa diversifikasi dan hilirisasi produk pertanian. Manfaat penelitian ini menghasilkan landasan teori yang dapat dijadikan referensi penelitian selanjutnya dan berguna bagi masyarakat petani yang akan memasarkan andaliman.
\end{abstract}

Kata Kunci : Andaliman, Kalsium klorida, Lama penyimpanan

\begin{abstract}
Andaliman (Zanthoxylum acanthopodium DC.) is a plant with characteristic is easily rotten and moldy, so postnatal care is needed after harvest. The proper method is preservation technique. This study was meant to know the effect of the CaCl2 (Calsium chloride) applications on long-storage andaliman (Zanthoxylum acanthopodium DC).

In previous study came the result that its best treatment was with infantile andaliman with Calsium chloride at a concentration of 0,45\% for 40 minutes. On this research will be applied Calsium chloride 0,45\% to see the old influence of andaliman storage. Andaliman will be stored at an old level of storage 4 days, 5 days, 6 days and 7 days. The parameters observed are water levels, weight shards, oil levels and organological tests of color, scent and texture. Research usess the complete design methods of factorial design that long storage consist of 4 levels $L 1=4$ days : $L 2=5$ days : $L 3=6$ days : L4=7 days. This study has the target of the publication of a scientific article in the national journal with ISSN. It refers to postexilic technologies and engineering food processing technologies of diversified and illiegal agricultural products. The benefit of this study yielded an underlying theory that could be used as afurther research reference and useful to a society of farmers who would market andaliman.
\end{abstract}

Keyword : Andaliman, Calsium chloride, long storage 


\section{PENDAHULUAN}

Desa Bandar Huta Usang merupakan salah satu daerah penghasil andaliman di Kecamatan Pegagan Hilir, Kabupaten Dairi. Andaliman yang dibudidayakan di desa ini ada dua varietas yaitu sihorbo dan simanuk. Tampak jelas perbedaan antara varietas sihorbo dengan simanuk.

Andaliman dengan nama latin Zanthoxylum acanthopodium DC memiliki ciri aromanya yang khas dan menimbulkan sensasi getir di lidah yang disebabkan adanya kandungan senyawa hydroxialpha sanshool pada rempah tersebut. Adanya informasi ilmiah mengenai khasiatnya dengan sendiri akan mendorong peningkatan penggunaannya. Selain diperlukan inovasi baru untuk mengembangkan berbagai bentuk produk olahan andaliman mengingat khasiatnya tidak terbatas sebagai bumbu masak.

Buah andaliman merupakan salah satu jenis bumbu utama masakan suku Batak, dimana tanpa adanya bumbu ini masakan dirasa kurang sempurna. Misalnya Saksang, Naniura, Nanigotaan maupun Arsik Ikan Mas. Pada masakan ini bila ditambahkan bumbu andaliman akan terasa lebih nikmat. Andaliman yang masih berwarna hijau lama kelamaan akan mengalami degradasi warna menjadi warna hitam dan teksturnya berubah dari segar menjadi kering tetapi aroma menjadi semakin wangi. Buah andaliman yang sudah kering dapat disimpan dalam jangka waktu yang lebih panjang tetapi harus disimpan pada suhu udara yang sejuk dan kering.

Produk pertanian memiliki ciri-ciri mudah busuk dan mudah rusak sehingga perlu penanganan pasca panen. Teknik pengolahan dan pengawetan dapat meminimalisir perubahan yang diakibatkan oleh mekanis, kimiawi, biologis, fisiologis maupun parasitik. Perubahan-perubahan ini sifatnya bisa menguntungkan dan bisa juga merugikan. Penelitian dan penggalian mengenai kandungan dan khasiat serta penganekaragaman produk andaliman maupun pengembangan pemanfaatan lain dari andaliman sangat perlu dilakukan. Adanya informasi ilmiah mengenai khasiatnya dengan sendirinya akan mendorong peningkatan penggunaannya. Inovasi baru sangat diperlukan dalam mengembangkan berbagai bentuk produk olahan andaliman karena khasiatnya tidak terbatas sebagai bumbu masakan. Upaya-upaya tersebut akan mendorong konsumsi andaliman tidak hanya di masyarakat Batak saja tetapi juga di luar suku Batak dan ini sangat menguntungkan bagi produsen andaliman dalam upaya menyerap produksinya.

Andaliman merupakan tumbuhan yang hanya terdapat di pegunungan yang terletak di Kabupaten Simalungun, Toba Samosir, Dairi, dan Tapanuli Utara, semuanya di Provinsi Sumatra Utara, pada daerah berketinggian $1.500 \mathrm{mdpl}$ dengan temperatur 15-18 o C. Tumbuhan ini merupakan salah satu jenis rempah yang belum banyak dikenal oleh masyarakat Indonesia. Padahal melihat keunikan sensorik yang dimiliki dan juga aktivitas fisiologi, bukan mustahil tumbuhan ini dapat menjadi salah satu rempah yang berpotensi merebut peluang pasar ekspor. Kandungan 259 Floribunda 5(7) 2017 senyawa dalam andaliman seperti senyawa trigeminal aktif yang berfungsi sebagai antioksidan dan antimikrob yang menjadikan tumbuhan ini sebagai bahan obat-obatan, selain sebagai bumbu masakan [1]. Wijaya dkk ( 2001).

1. Kalsium Klorida $(\mathrm{CaCl} 2)$

Penyusutan atau kehilangan (loss) hasil panen dapat terjadi pada setiap tahap pengolahan. Mulai dari panen, penanganan segera setelah panen, penyimpanan, pengolahan, dan pengangkutan [2] Syarief dan Irawati (1988).

Kalsium Klorida $(\mathrm{CaCl} 2)$ merupakan Bahan Tambahan Pangan (BTP) yang mempunyai toksisitas sangat rendah, berdasarkan data (kimia, biokimia, toksikologi dan data lainnya) dan telah mendapat Izin dari Badan Pengawas Obat dan Makanan Republik Indonesia Nomor 24 Tahun 2013 tentang Batas Maksimum Penggunaan Bahan Tambahan Pangan. Joint FAO/WHO Expert Committee on Food Additives (JECFA) telah mengevaluasi BTP kalsium klorida yang diperlakukan pada buah kalengan, tunggal atau campuran dengan pengeras dinyatakan aman atau generally recognize as safe (GRAS) dengan batas maksium penggunaan $350 \mathrm{~g} / \mathrm{kg}$ [3]. Faiqoh (2014). 
Perlakuan $\mathrm{CaCl} 2$ dapat dilakukan dengan beberapa cara diantaranya adalah perendaman dengan hipobarik, metode temperature gradient, mengurangi tegangan permukaan atau pemakaian surfaktan dan perendaman dalam suhu kamar. Perubahan kekerasan buah dapat dipertahankan dengan pemakaian kalsium. Kalsium akan bereaksi dengan gugus karboksi dari pektin, karena kalsium bervalensi dua maka akan terjadi ikatan menyilang diantara 2 gugus karboksi tersebut [4]. Winarno dan Aman (1981).

2. Analisis Proksimat

Analisis proksimat merupakan analisis kandungan makro suatu bahan makanan. Analisis proksimat adalah analisis yang dapat dikatakan berdasarkan perkiraan saja, tetapi sudah dapat menggambarkan komposisi bahan yang dimaksud [5]. Sumartini dan Kantasubrata (1992). Analisis proksimat terdiri dari: kadar air, kadar abu, kadar protein, kadar lemak, dan kadar karbohidrat.

3. Uji Organoleptik

Pengujian organoleptik adalah pengujian yang didasarkan pada proses pengindraan. Uji organoleptik (evaluasi sensori) adalah penilaian berdasarkan kepada rangsangan syaraf sensori pada indra (organ tubuh) manusia atau disebut juga penilaian indrawi karena mengukur sifat sifat indrawi [6]. Muhandri dkk (2012).

Metode analisa sensori/ oraganoleptik yang digunakan, yaitu [7]. Setyaningsih dkk (2010).

\section{Uji Kesukaan (Hedonik)}

Uji kesukaan (hedonik) dilakukan apabila uji didesain untuk memilih satu produk diantara produk lain secara langsung. Uji ini dapat diaplikasikan pada saat pengembangan produk atau perbandingan produk 10 pesaing. Uji kesukaan meminta panelis untuk harus memilih satu pilihan diantara pilihan yang lain. Maka itu, produk yang tidak dipilih menunjukkan bahwa produk tersebut disukai ataupun tidak disukai. Skala hedonik yang bisa digunakan adalah: amat sangat suka, sangat suka, suka, agak suka, biasa saja, agak tidak suka, tidak suka, sangat tidak suka, amat sangat tidak suka. Skala hedonik ini dapat direntangkan atau diciutkan menurut rentangan skala yang dikehendaki. Skala hedonik dapat juga diubah menjadi skala numerik dengan angka menurut tingkat kesukaan. Dengan data numerik ini dapat dilakukan analisis secara parametrik. Hasil yang paling baik diperoleh dari skala yang seimbang, yaitu yang jumlahnya ganjil, misalnya skala $1-3,1-5$, $1-7$, dan $1-9$. Penggunaan skala hedonik ini pada prakteknya dapat digunakan untuk mengetahui perbedaan, sehingga uji hedonik sering digunakan untuk menilai secara oraganoleptik komoditas sejenis atau produk pengembangan uji hedonik banyak digunakan untuk menilai produk akhir. Semua sampel yang disajikan harus diberi kode. Pemberian kode yang dianjurkan menggunakan angka 3 digit, tidak ada sampel yang kodenya sama dan berulang. Pemberian kode bukan dengan huruf, dengan tujuan untuk menghilangkan bias.

2. Uji Mutu Hedonik

Berbeda dengan uji kesukaan, uji mutu hedonik tidak menyatakan suka atau tidak suka, melainkan menyatakan kesan tentang baik atau buruk. Kesan baik atau buruk ini disebut kesan mutu hedonik. Oleh karena itu, beberapa ahli memasukkan uji mutu hedonik kedalam uji hedonik. Kesan mutu hedonik lebih spesifik daripada sekedar kesan suka atau tidak. Mutu hedonik dapat bersifat umum, yaitu baik atau buruk dan bersifat spesifik seperti empuk - keras untuk daging, pulen keras untuk nasi, dan renyah untuk mentimun.

\section{METODE PELAKSANAAN}

Andaliman diperoleh dari masyarakat petani desa Bandar Huta Usang Kabupaten Dairi, kemudian dilakukan analisa terhadap sampel andaliman di laboratorium. Adapun analisis yang dilakukan adalah perendaman dengan kalium klorida sebesar $0,45 \%$ selama 40 menit kemudian dilakukan penyimpanan selama 4,5,6 dan 7 hari, setelahnya dilakukan uji proksimat berupa analisa kadar air, susut bobot, kadar minyak atsiri dan nilai organoleptik terhadap warna, aroma dan tekstur.

\section{HASIL DAN PEMBAHASAN}

Hasil yang dicapai dari penelitian tentang upaya memperpanjang masa simpan andaliman adalah berupa kadar air, susut bobot, kadar minyak atsiri dan uji organoleptik. 


\section{Kadar Air}

Pengaruh lama perendaman Kalsium Klorida sebesar $0,45 \%$ selama 40 menit terhadap kadar air dapat dilihat pada gambar 1 .

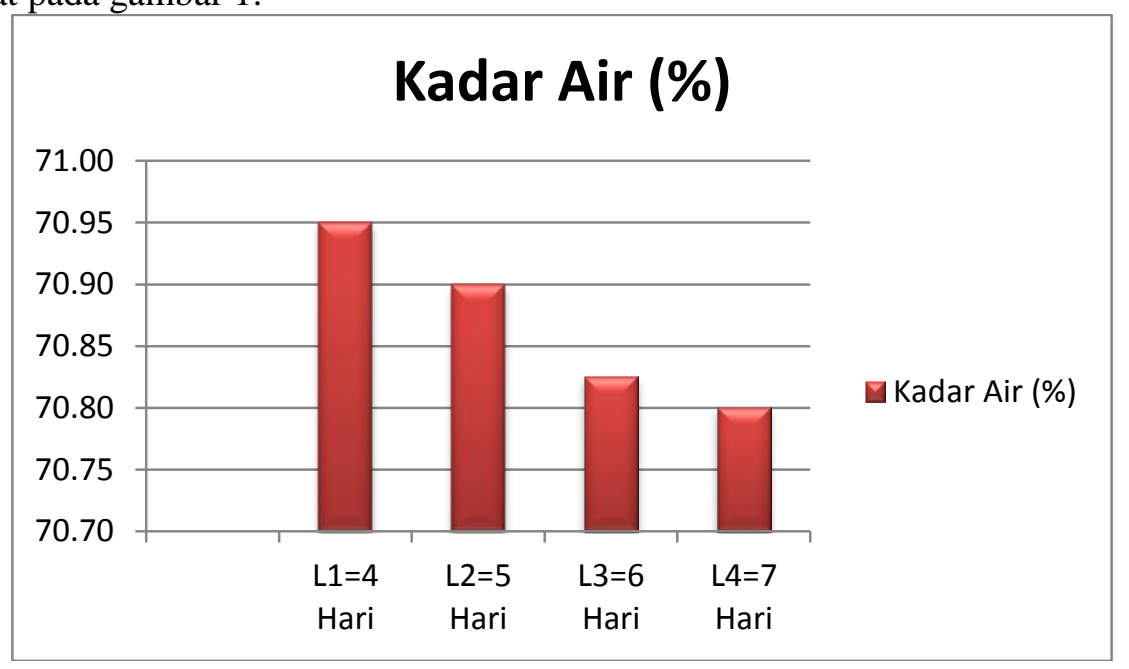

Gambar 1. Pengaruh Lama Perendaman Kalsium klorida 0,45\% selama 40 menit terhadap kadar air Dari hasil analisa diperoleh bahwa pengaruh lama perendaman kalsium klorida sebesar 0,45\% selama 40 menit terhadap kadar air berbeda sangat nyata. Kadar air tertinggi terdapat pada L1 (Penyimpanan 4 hari) sebesar $70,95 \%$ dan yang terendah terdapat pada L4 (Penyimpanan 7 hari) sebesar $70,80 \%$. Menurut Suyanti dan Sjaifullah, (1998) bahwa perendaman bahan dalam $\mathrm{CaCl}_{2}$ berfungsi menahan laju transpirasi air dari bahan dan juga menahan laju penguapan senyawasenyawa yang mudah menguap dari bahan serta dapat mempertahankan teksturnya yang baik.

\section{Susut Bobot}

Pengaruh lama perendaman Kalsium Klorida sebesar $0,45 \%$ selama 40 menit terhadap susut bobot dapat dilihat pada gambar 2 .

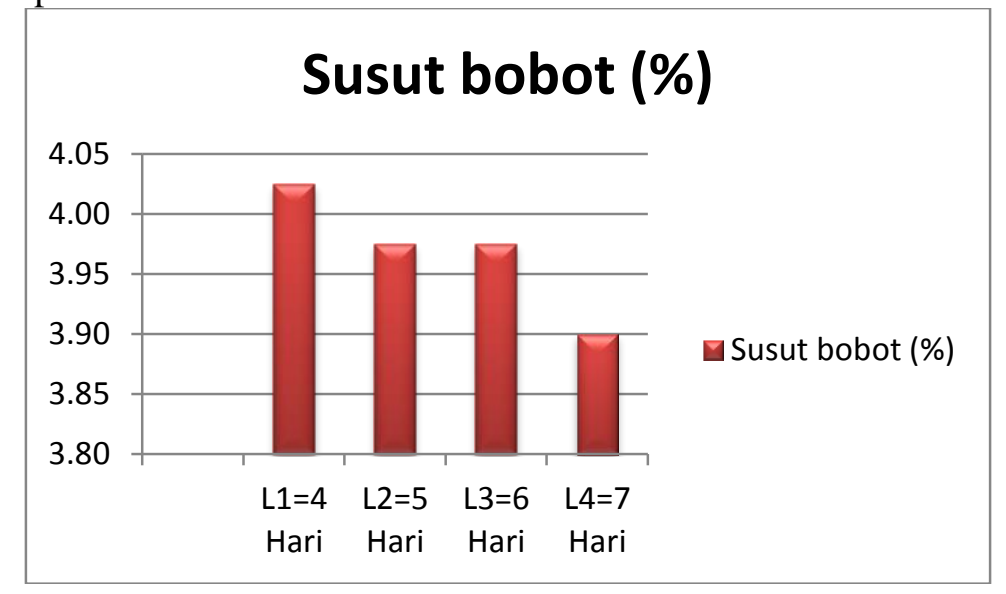

Gambar 2. Pengaruh Lama Perendaman Kalsium klorida 0,45\% selama 40 menit terhadap susut bobot Dari hasil analisa diperoleh bahwa pengaruh lama perendaman kalsium klorida sebesar $0,45 \%$ selama 40 menit terhadap susut bobot berbeda sangat nyata. Susut bobot tertinggi terdapat pada L1 (Penyimpanan 4 hari) sebesar $4,03 \%$ dan yang terendah terdapat pada L4 (Penyimpanan 7 hari) sebesar 3,90\%. Kalsium klorida mudah larut sehingga ion kalsium mudah berpenetrasi ke dalam jaringn membentuk komplek kaslium pektat yang mampu menahan air keluar dari bahan (Sudjud,2000).

\section{Kadar Minyak Atsiri}

Pengaruh lama perendaman Kalsium Klorida sebesar $0,45 \%$ selama 40 menit terhadap kadar minyak atsiri dapat dilihat pada gambar 3 . 


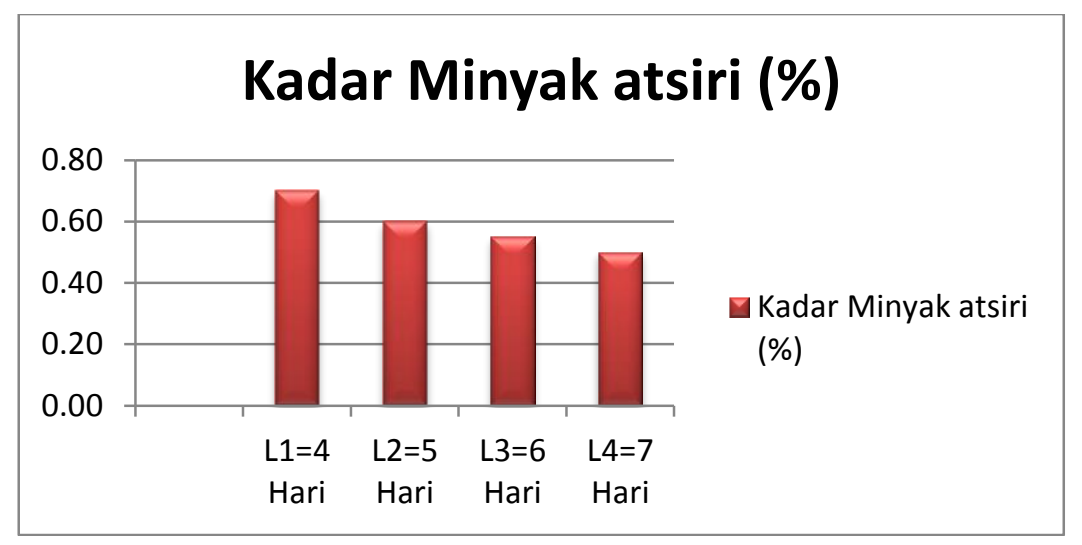

Gambar 3. Pengaruh Lama Perendaman Kalsium klorida 0,45\% selama 40 menit terhadap kadar minyak atsiri

Dari hasil analisa diperoleh bahwa pengaruh lama perendaman kalsium klorida sebesar 0,45\% selama 40 menit terhadap kadar minyak atsiri berbeda sangat nyata. Kadar minyak atsiri tertinggi terdapat pada L1 (Penyimpanan 4 hari) sebesar $0,70 \%$ dan yang terendah terdapat pada L4 (Penyimpanan 7 hari) sebesar 0,50\%. Menurut Suyanti dan Sjaifullah, (1998) bahwa perendaman bahan dalam $\mathrm{CaCl}_{2}$ berfungsi menahan laju transpirasi air dari bahan dan juga menahan laju penguapan senyawa-senyawa yang mudah menguap dari bahan serta dapat mempertahankan teksturnya yang baik.

Nilai Organoleptik Warna (Numerik)

Pengaruh lama perendaman Kalsium Klorida sebesar $0,45 \%$ selama 40 menit terhadap nilai organoleptik warna dapat dilihat pada gambar 4.

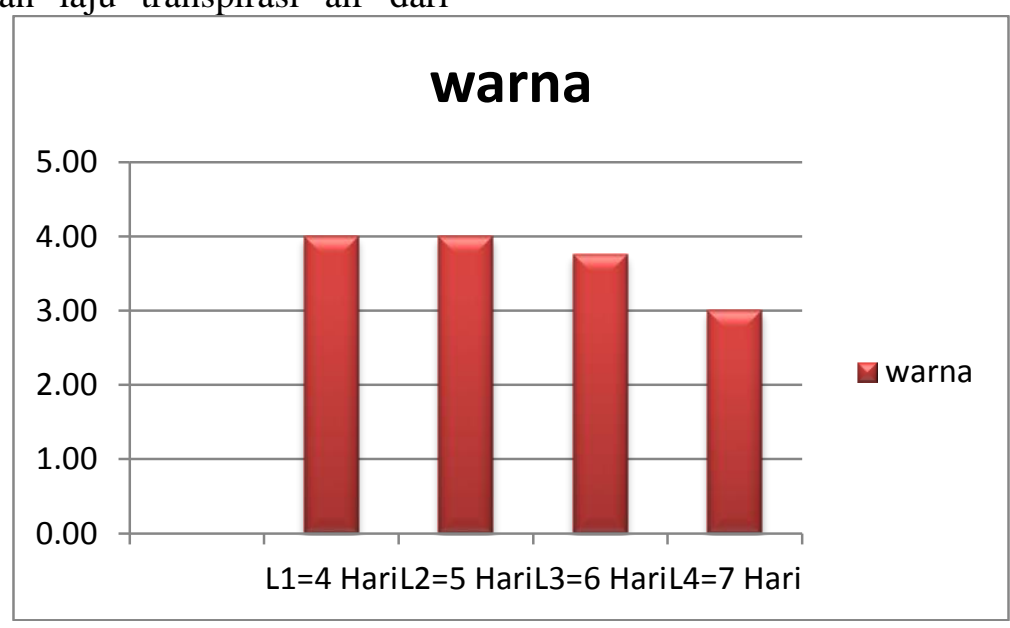

Gambar 4. Pengaruh Lama Perendaman Kalsium klorida 0,45\% selama 40 menit terhadap nilai organoleptik warna

Dari hasil analisa diperoleh bahwa pengaruh lama perendaman kalsium klorida sebesar $0,45 \%$ selama 40 menit terhadap nilai organoleptik warna berbeda sangat nyata. Nilai organoleptik warna tertinggi terdapat pada L1 (Penyimpanan 4 hari) sebesar 4,00 dan yang terendah terdapat pada L4

\section{Nilai Organoleptik Aroma (Numerik)}

Pengaruh lama perendaman Kalsium Klorida sebesar $0,45 \%$ selama 40 menit terhadap nilai organoleptik aroma dapat dilihat pada gambar 5.

(Penyimpanan 7 hari) sebesar 3,00. 


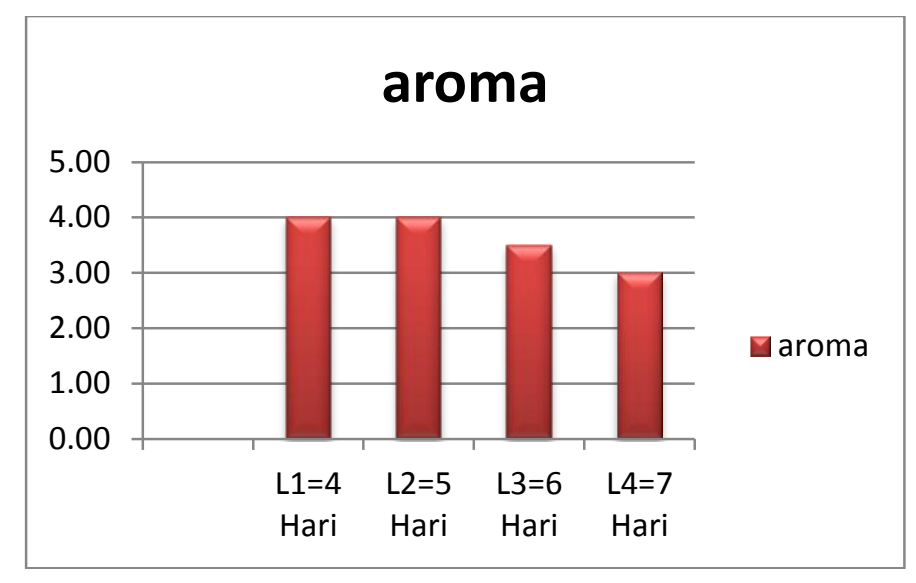

Gambar 5. Pengaruh Lama Perendaman Kalsium klorida $0,45 \%$ selama 40 menit terhadap nilai organoleptik aroma

Dari hasil analisa diperoleh bahwa pengaruh lama perendaman kalsium klorida sebesar $0,45 \%$ selama 40 menit terhadap nilai organoleptik aroma berbeda sangat nyata. Nilai organoleptik aroma tertinggi terdapat pada L1 (Penyimpanan 4 hari) sebesar 4,00 dan yang terendah terdapat pada L4 (Penyimpanan 7 hari) sebesar 3,00.

Nilai Organoleptik Tekstur (Numerik) Pengaruh lama perendaman Kalsium Klorida sebesar 0,45\% selama 40 menit terhadap nilai organoleptik tekstur dapat dilihat pada gambar 6.

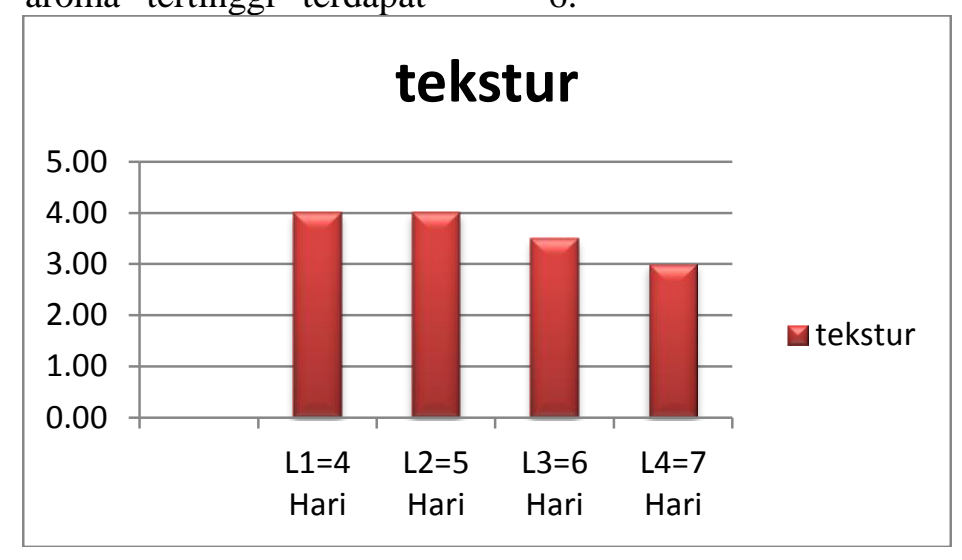

Gambar 6. Pengaruh Lama Perendaman Kalsium klorida $0,45 \%$ selama 40 menit terhadap nilai organoleptik aroma

Dari hasil analisa diperoleh bahwa pengaruh lama perendaman kalsium klorida sebesar $0,45 \%$ selama 40 menit terhadap nilai organoleptik tekstur berbeda sangat nyata. Nilai organoleptik tekstur tertinggi terdapat pada L1 (Penyimpanan 4 hari) sebesar 4,00 dan yang terendah terdapat pada L4 (Penyimpanan 7 hari) sebesar 3,00.

\section{KESIMPULAN DAN SARAN}

\section{Kesimpulan}

Dari hasil penelitian upaya memperpanjang masa simpan andaliman terhadap parameter yang diamati dapat disimpulkan sebagai berikut :
1. Lama penyimpanan $4,5,6$ dan 7 hari dengan menggunakan konsentrasi Kalsium klorida 0,45\% selama 40 menit berpengaruh nyata terhadap kadar air, susut bobot dan kadar minyak atsiri.

2. Lama Penyimpanan 7 hari berpengaruh nyata terhadap nilai organoleptik warna andaliman.

\section{Saran}

1. Untuk memperpanjang masa simpan andaliman disarankan menggunakan konsentrasi kalsium Karbonat 0,45\% selama 40 menit.

2. Perlu diteliti lebih lanjut metode lain dalam upaya memperpanjang umur simpan andaliman.

\section{DAFTAR PUSTAKA}


1. Wijaya $\mathrm{CH}$, Hadiprodjo IT, Apriyantono A. 2001. Komponen volatil dan karakterisasi komponen kunci aroma buah andaliman (Zanthoxylum acanthopodium DC.). J Teknol Industri Pangan 12:117125.

2. Syarief, R dan Irawati, 1988. Pengetahuan Bahan Untuk Industri Pertanian. Jakarta :Mediyatama Sarana Perkasa.

3. Faiqoh, Elmaulida N. 2014. Pengarh Konsentrasi Dan Lama Perendaman Dalam CaCl2 (Kalsium klorida) Terhadap Kualitas Dan Umur Simpan Buah Naga Super Merah.

4. Winarno, F.G dan M. Aman, 1981. Fisiologi Lepas Panen. Sastra Budaya, Jakarta.
5. Muhandri, Tjahja,dkk.2012. Komposisi Kimia Tepung Jagung varietas Unggul Lokal dan Potensinya untuk Pembuatan Mi Jagung Menggunakan Ekstruder Pencetak. Jurnal sains terapan EDISI II vol 2(1). Bogor : IPB

6. Suyanti dan Sjaifullah, 1998. Pengaruh Blansing dan Cara Penggorengan Terhadap Mutu Minyak Keripik Pepaya Sisa Sadap. SKRIPSI FATETA, Bogor

7. Sumartini S, Kantasubrata J.1992. Analisis Proksimat 1 dan 2. Kursus Teknik Kimia Pangan. P3KT-LIPI: Bandung 